\title{
Hiehojen rahtikasvatuksen kannattavuus emolehmätiloilla
}

\author{
Seppo Mönkkönen ${ }^{1)}$, Hannu Viitala ${ }^{1)}$, Risto Kauppinen ${ }^{1)}$, Arto Huuskonen ${ }^{2)}$ ja Maiju Pesonen ${ }^{2)}$ \\ 1) Savonia-ammattikorkeakoulu, PL 72, 74101 Iisalmi, etunimi.sukunimi@savonia.fi \\ ${ }^{2)}$ Luonnonvarakeskus (Luke), Vihreä teknologia, Tutkimusasemantie 15, 92400 Ruukki, \\ etunimi.sukunimi@luke.fi
}

\section{Tiivistelmä}

Kehitystä naudanlihantuotantoon -hankkeessa hiehojen kasvatuksen kustannuksia vertailtiin kahdella pohjoissavolaisella emotilalla ja yhdellä talouslaskelmiin nojaavalla tilamallilla. Hiehojen tuotantokustannuksesta rehujen osuus on merkittävä. Rehujen hintoina käytettiin markkinahintoja eikä tilahintoja. Näin laskelmista saatiin vertailukelpoisia. Jos tilan rehuntuotanto on kovin kallista, ei hiehonkasvatuksen kustannuksella ole merkitystä kokonaisuudessa. Tällöin hiehon tuotantokustannuksesta ei saa todellista kuvaa. Tilamallien lähtökohtana oli, että hiehot kasvatetaan tilalla, ja tätä vertaillaan hiehonkasvatuksen ulkoistamiseen eri päiväkasvatushinnoilla. Ulkoistamisvaihtoehdossa eläimet siirrettiin kasvattamoon vieroituksen jälkeen 6 kuukauden iässä. Kasvattamoaika oli 12 kuukautta tai vaihtoehtoisesti 18 kuukautta.

Kasvattamossa hiehoja pystytään kasvattamaan tietyin edellytyksin halvemmalla kuin omalla tilalla. Tilalla hiehon kasvatuspäivä maksaa 3,55-4,10 euroa. Ulkoistettaessa kasvatuskustannus vaihtelee 3,38 eurosta 3,44 euroon, kun kasvatuspäivän hinta on 2 euroa ja kasvatusaika 18 kuukautta. Kuljetuskustannuksena on käytetty 2,5 euroa kilometriltä. Emolehmätuottajan kannalta kiinnostavampi vaihtoehto kasvatusajaksi olisi 12 kuukautta. Tämä siksi, että eläimiä karsittaessa tilan tuotantorakennukseen ei jää tyhjiä paikkoja. Hiehokasvattamon kannalta 12 kuukauden kasvatusaika mahdollistaa kapasiteetin tehokkaimman käytön. Logistiikka olisi myös tällöin helpompi hoitaa, koska uudistuseläinten paluukuormassa voidaan viedä vasikoita kasvattamoon.

Hiehonkasvatuksen ulkoistamisen vaihtoehdossa rahtikasvatus mallinnettiin tilalle, jossa kasvattamon koko oli 90 hiehoa. Hiehot tulivat kasvattamoon lokakuussa kuuden kuukauden ikäisinä ja palasivat emotilalle tiineinä. Jos päiväkasvatushinta on kaksi euroa, hiehon ulkoistuksen hinnaksi muodostuu 18 kuukaudelta 1080 euroa. Päiväkasvatushinta vaihtelee 0,74-4,0 euroon.

Jos uudistuseläinten tuotanto on omalla tilalla edullista, kasvattamon käyttö ei tuo erityistä lisähyötyä. Ulkoistamisen kannattavuuden emotilalla ratkaisee se, saadaanko tuotantoa tehostettua eli käytännössä saadaanko emojen määrää lisättyä ulkoistamisen ansiosta.

Kasvattamon perustaminen ja päätoiminen pyörittäminen on käytännössä vaikeaa, koska kannattava toiminta vaatii paljon kasvatettavia hiehoja. Lypsykarjapuolella hiehokasvattamossa tulisi olla mielellään vähintään 150 hiehoa kasvatuksessa, jotta toiminta olisi kannattavaa. Kasvattamon taloudellista toimintaa vaikeuttaa se, että kasvattamo ei saa tukia. Lisäksi päiväkasvatushinnan tulee olla juuri oikea, että se peittäisi kaikki aiheutuvat kulut. Päätoiminen uudistuseläinten kasvatus on taloudellisesti varsin haastavaa. Toiminta sopisi emotiloille, joilla on ylimääräisiä tyhjiä rakennuksia. Vanhat toimivat rakennukset parantavat kasvattamon kannattavuutta. Kasvatustoiminta voisi tuoda lisäansioita päätuotannon ohelle. Tällöin kasvattamo voisi toimia vähemmillä uudistuseläimillä.

Asiasanat: emolehmätuotanto, hiehot, rahtikasvatus, kasvattamo, kannattavuus 


\section{Johdanto}

Emolehmätuotannossa uudistushiehot kasvatetaan pääsääntöisesti kotitilalla, mutta kiinnostusta on myös tilan ulkopuolella tapahtuvaan kasvatukseen. Ulkoistamisen hyötyinä nähdään työmäärän väheneminen sekä ruokinta- ja laidunnusratkaisujen yksinkertaistuminen. Eläinten ryhmittely on yksinkertaisempaa, eikä hiehoille välttämättä tarvita omaa sonnia. Runsas viidennes emotiloista on kiinnostunut uudistushiehojen kasvatuksen ulkoistamisesta. Kasvatuspäivästä maksettava hinta ratkaisee ulkoistamisen hyödyt emotilalla ja samalla rahtikasvattajan investoinnin kannattavuuden. Kehitystä naudanlihantuotantoon -hankkeessa selvitettiin hiehon päiväkohtainen tuotantokustannus emotilalla. Päiväkasvatushinnan vaikutusta rahtikasvattamon investointien kannattavuuteen tutkittiin 90-paikkaisen hiehokasvattamon mallinnuksella.

\section{Aineisto ja menetelmät}

Hiehojen kasvatuksen kustannuksia vertailtiin kahdella pohjoissavolaisella emotilalla ja yhdellä talouslaskelmiin nojaavalla tilamallilla. Hiehojen tuotantokustannuksesta rehujen osuus on merkittävä. Rehujen hintoina käytettiin markkinahintoja eikä tilahintoja. Näin laskelmista saatiin vertailukelpoisia. Jos tilan rehuntuotanto on kovin kallista, ei hiehonkasvatuksen kustannuksella ole merkitystä kokonaisuudessa. Tällöin hiehon tuotantokustannuksesta ei saa todellista kuvaa.

Tilamallien lähtökohtana oli, että hiehot kasvatetaan tilalla, ja tätä vertaillaan hiehonkasvatuksen ulkoistamiseen eri päiväkasvatushinnoilla. Ulkoistamisvaihtoehdossa eläimet siirretään kasvattamoon vieroituksen jälkeen 6 kuukauden iässä. Kasvattamoaika on 12 kuukautta tai vaihtoehtoisesti 18 kuukautta.

Tila 1 oli Pohjois-Savossa sijaitseva emotila, jossa on 85 emolehmää ja 16 uudistushiehoa. Uudistuseläimet ostetaan tilalle vasikkana. Tilan tuotantosuunta on pihvivasikantuotanto. Karjan rotu on pääosin hereford. Laidunta on 51 ja säilörehunurmea 52 hehtaaria. Kotieläintöitä kertyy 1400 tuntia vuodessa.

Tila 2 oli myös pihvivasikantuotantoon suuntautunut. Karjaa on 40 emoa ja 7 hiehoa, pääosin herefordia. Säilörehualaa on 29 ja laidunta 31 hehtaaria. Kotieläintyötä on 600 tuntia vuodessa.

Tila 3 eli teoreettinen tilamalli pohjautui erilaisiin lähteisiin maatalouden kustannuksista. Mallitilalla oli 75 emolehmää ja 14 hiehoa. Peltoala oli 85 hehtaaria, josta 45 hehtaaria säilörehua ja loput laidunta. Kone- ja rakennuskustannukset sekä muuttuvat kustannukset olivat keskimääräiset mallitilojen mukaiset kustannukset.

\section{Tulokset ja tulosten tarkastelu}

Kasvattamossa hiehoja pystytään kasvattamaan tietyin edellytyksin halvemmalla kuin omalla tilalla. Tilalla hiehon kasvatuspäivä maksaa 3,55-4,10 euroa. Ulkoistettaessa kasvatuskustannus vaihtelee 3,38 eurosta 3,44 euroon, kun kasvatuspäivän hinta on 2 euroa ja kasvatusaika 18 kuukautta (Taulukko 1). Kuljetuskustannuksena on käytetty 2,5 euroa kilometriltä.

Emolehmätuottajan kannalta kiinnostavampi vaihtoehto kasvatusajaksi olisi 12 kuukautta. Tämä siksi, että eläimiä karsittaessa tilan tuotantorakennukseen ei jää tyhjiä paikkoja. Hiehokasvattamon kannalta 12 kuukauden kasvatusaika mahdollistaa kapasiteetin tehokkaimman käytön. Logistiikka olisi myös tällöin helpompi hoitaa, koska uudistuseläinten paluukuormassa voidaan viedä vasikoita kasvattamoon.

Hiehonkasvatuksen ulkoistamisen vaihtoehdossa rahtikasvatus mallinnettiin tilalle, jossa kasvattamon koko oli 90 hiehoa. Hiehot tulivat kasvattamoon lokakuussa kuuden kuukauden ikäisinä ja palasivat emotilalle tiineinä. Jos päiväkasvatushinta on kaksi euroa, niin hiehon ulkoistuksen hinnaksi muodostuu 18 kuukaudelta 1080 euroa. Päiväkasvatushinta vaihtelee 0,74-4,0 euroon. 
Taulukko 1. Päiväkohtainen hiehon tuotantokustannus emotiloilla sekä eri kasvatuspäivähinnoilla lasketut tuotantokustannukset päivää kohti. Taulukossa on merkitty vihreällä, kun tuotantokustannus on edullisempi ulkoistamalla kuin omalla kasvatuksella ja punaisella kun ulkoistamisvaihtoehto on kalliimpi kuin hiehon oma kasvatus.

\begin{tabular}{|c|c|c|c|}
\hline & Emotila 1, $\boldsymbol{\epsilon} / \mathbf{p v}$ & Emotila 2, $\boldsymbol{\epsilon} / \mathbf{p v}$ & Emotila malli, $\boldsymbol{\epsilon} / \mathbf{p v}$ \\
\hline Omalla tilalla kasvatus & $\mathbf{3 , 5 5}$ & $\mathbf{3 , 9 2}$ & $\mathbf{4 , 1 0}$ \\
\hline $\begin{array}{c}\text { Kasvatuspäivähinta } \\
\text { ulkoistettaessa }\end{array}$ & & & \\
\hline $2 € / \mathrm{pv}, 18 \mathrm{kk}$ & 3,38 & & \\
\hline $2,1 € / \mathrm{pv}, 18 \mathrm{kk}$ & 3,48 & 3,44 & 3,43 \\
\hline $2,2 € / \mathrm{pv}, 18 \mathrm{kk}$ & 3,57 & 3,54 & 3,52 \\
\hline $2,3 € / \mathrm{pv}, 18 \mathrm{kk}$ & 3,67 & 3,63 & 3,62 \\
\hline $2,5 € / \mathrm{pv}, 18 \mathrm{kk}$ & 3,86 & 3,73 & 3,71 \\
\hline $2,7 € / \mathrm{pv}, 18 \mathrm{kk}$ & 4,05 & 3,92 & 3,90 \\
\hline
\end{tabular}

Taulukossa 2 on laskennallisilla päiväkasvatushinnoilla haettu kasvattamon korkeinta hintaa, jolla investointi olisi vielä kannattava. Investointi on laskettu 15 vuoden kuoletusajalla ja 5 prosentin korolla niin, että jäännösarvo on lopussa nolla. Laskelmat on tehty 80 prosentin täyttöasteella, koska 100 prosentin täyttö ei ole todennäköinen. Täyttöasteella on suuri vaikutus kasvattamon kannattavuuteen ja kasvattajan tulisi jatkuvasti pyrkiä lähemmäs 100 prosentin täyttöastetta. Kasvatuspäivän hinnalla 1,81 euroa kasvattamo saisi maksaa enintään 112000 euroa, jotta investointi olisi kannattava.

Taulukko 2. Laskennalliset päiväkasvatushinnat, joilla 90 hiehopaikan kasvattamoinvestointi olisi vielä kannattava.

\begin{tabular}{ccc}
\hline Kasvatuspäivän hinta, $€ /$ pv & Kasvattamon hinta enintään, $€$ & Eläinpaikan hinta enintään, $€$ \\
\hline 0,74 & Ei kata kuluja & Ei kata kuluja \\
1,81 & 112000 & 1244 \\
2,00 & 156000 & 1733 \\
2,50 & 272000 & 3022 \\
2,88 & 360000 & 4000 \\
3,00 & 388000 & 4311 \\
\hline
\end{tabular}

Kasvattamon eläinpaikan hinnaksi muodostuu 1244-4311 euroa riippuen investoinnin suuruudesta. Hiehokasvattamo ei ole oikeutettu EU:n nautapalkkioon, jos hiehojen lukumäärä on suurempi kuin enintään 40 prosenttia tilan eläinyksikkömäärästä. Hiehoja kasvattavalla tilalla pitäisi olla emolehmiä, jotta myös rahtikasvatettavista hiehoista saisi tukia.

\section{Yhteenveto ja johtopäätökset}

Emotiloille suunnatussa ulkoistamista koskevassa kyselyssä selvisi, että eniten emotiloja mietityttävät tautiriskit. Eläintautien torjunnassa tehokkain tapa on pitää hiehokasvattamon asiakastilojen määrä mahdollisimman pienenä. Tämä on haasteellista. Emotilat ovat Suomessa vielä toistaiseksi keskimäärin melko pieniä ja tarvitsevat vuosittain 3-8 uudistuseläintä. Pohdintaa aiheutti myös se, miten eläimet tottuvat käsittelyyn ja sopeutuvat emolehmätilan omaan kasvatusympäristöön.

Jos uudistuseläinten tuotanto on omalla tilalla edullista, kasvattamon käyttö ei tuo erityistä lisähyötyä. Ulkoistamisen kannattavuuden emotilalla ratkaisee se, saadaanko tuotantoa tehostettua eli käytännössä saadaanko emojen määrää lisättyä ulkoistamisen ansiosta. Kasvattamon perustaminen ja päätoiminen pyörittäminen on käytännössä vaikeaa, koska kannattava toiminta vaatii paljon kasvatettavia hiehoja. Lypsykarjapuolella hiehokasvattamossa tulisi olla mielellään vähintään 150 hiehoa kasvatuksessa, jotta toiminta olisi kannattavaa. Kasvattamon taloudellista toimintaa vaikeuttaa se, että kasvattamo ei saa tukia. Lisäksi päiväkasvatushinnan tulee olla juuri oikea, että se peittäisi kaikki aiheutuvat kulut. Päätoiminen uudistuseläinten kasvatus on taloudellisesti varsin haastavaa. Toiminta sopisi emotiloille, joilla on ylimääräisiä tyhjiä rakennuksia. Vanhat toimivat rakennukset parantavat kasvattamon kannattavuutta. Kasvatustoiminta voisi tuoda lisäansioita päätuotannon ohelle. Tällöin kasvattamo voisi toimia vähemmillä uudistuseläimillä. 